\title{
鉱石ぺレット積込多時に船倉壁面に 加わ压力分布
}

\author{
正員山本 善 之* 正員 浦 環** \\ Initial Stress Distribution of Ore in Cargo Holds \\ by Yoshiyuki Yamamoto, Member Tamaki Ura, Member \\ Summary
}

The purposes of this paper are to describe an effective method of simulating the loading process of ore cargoes in large ore carrier, and to determine the initial stress distribution of ore in a cargo hold. The experimental data on an actual ship by Hagiwara et al. ${ }^{7}$ ) are compared with the result of the present method, and they show fairly good agreement. Various loading processes and types of ore hold are analyzed. From the comparison of these results, the authors come to the conclusion that the initial stress distribution of ore in an ore carrier in still water can be approximately determined by the formulation on the basis of the concept of the earth pressure at rest, which can be derived theoretically from the elastic constitutive equation for granular media proposed in the previous papers $[1,2]$.

\section{1 は じめ に}

著者らは波浪外力などによる鉱石ペレットの静的な応答を船体構造の横強度解析にぞのように適用するかにつ いて研究し，鉱石と船体構造を一つの構造系として考える必要があり，鉱石を船体変形とは無関係な外力に置き 換えることは適当でないと前論文に拈いて強調しだ,2)。

鉱石圧 $p$ は，初期圧力 $p^{\text {in }}$ 扣よび，外力による変動成分 $\Delta p$ の和

$$
p=p^{\text {in }}+\Delta p
$$

として表わされる。ここで，変動成分 $\Delta p$ は船体構造一鉱石ペレットより なる構造系の外力に対する応答を計算することにより求められる。これに 対して, 初期圧力 $p^{\text {in }}$,すなわち鉱石の初期応力状態は, 今まで実験によ

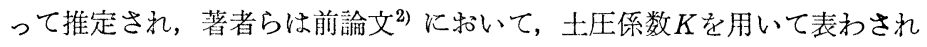
る状態 (Fig. 1 参照)

$$
\begin{aligned}
\sigma_{x} & =\sigma_{z}=K \sigma_{y}=-K h \gamma \\
\sigma_{y} & =-h \gamma \\
\tau_{x y} & =\tau_{y z}=\tau_{z x}=0
\end{aligned}
$$

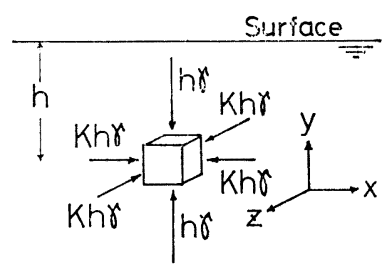

Fig. 1 静止土圧状態

をこの初期応力と仮定した。

実船の内底板付近では，銨不深さhがいちじるしく大きくなる。したがって (1) 式によれば鉣石応力が非常に 大きくなるので，検討を要することが明らかとなった。本論文では，このような初期応力を数值的にシミュレー ションの手法を用いて検討する。

半無限水平地盤での土压係数は一般に静止土压係数とよばれ $0.2 \sim 1.0$ 程度の值をとることが知られている。 そして粘性のない砂質土の静止土圧係数 $K_{0}$ に関して Jáky は

\footnotetext{
* 東京大学工学部
}

** 東京大学工学系大学院 


$$
K_{0}=1-\sin \phi
$$

なる実験式を提案している ${ }^{3)}$ ここでфは土の内部摩擦角である。この静止土圧係数による初期鉱石圧の議論は 非常に単純ではある。しかし，船倉内では，壁面の摩擦力が初期応力状態に大きな影響を及洼すとともに，鈗石 が船倉内に積込まれるにしたがって契水が刻々变化するので, 鉱石の応力状態がこのような式で表わされると簡 単には結論できない。また, 水平地盤とは異なり, 鉱石はセンター・ラインをほぼ中心にして山形汇積み上げら れこれによる影響も同時に考慮されなくてはならない。

以下， 2 節では先に著者らが導いた弾性構成方程式より理論的に静止土圧係数を導く。 3 節では, 船倉形状の 影響，鿄水の变化等を考慮するための手法として，鉱石積込みプロセスのシミュレーションについて述べる。 4 節ではこの手法を用いて計算される綐通隔壁上の圧力分布を, 萩原》により行なわれた実船実験の計測結果と比 較する。次に, 種々の積込みプロセスの違いによる初期圧力の差を数值実験により示す。また, 縱通隔壁下部に 斜板がある船倉の斜板上の圧力分有を示す。

\section{2 静止土圧係数}

まず，弾性理論により導かれる静止土圧係数について述べる。(1) 式で表わされる応力状態を考兄る。鉛直方 向の応力 $\sigma_{y}$ が $\Delta \sigma_{y}$ 増加するとき, 水平方向の応力増加 $\Delta \sigma_{x}, \Delta \sigma_{z}$ が

$$
\Delta \sigma_{x}=\Delta \sigma_{z}=K \Delta \sigma_{y}
$$

であるような初期応力比 $K$ を静止土圧係数 $K_{0}$ と呼ぶ。この状態での水平方向の歪増加 $\Delta \varepsilon_{x}, \Delta \varepsilon_{z}$ は

$$
\Delta \varepsilon_{x}=\Delta \varepsilon_{z}=0
$$

であり，(1)，(3) 式，拉よび文献 2)の (18) 式より $K_{0}$ は次の条件式により定められる。

$$
18 C_{1}\left(1+2 K_{0}\right)^{4}-3 C_{2}\left(1+2 K_{0}\right)^{3}\left(1-K_{0}\right)-2 C_{3}\left(1-K_{0}\right)^{3}\left(2+K_{0}\right)=0
$$

したがって，半無限に広がった粒状体がこの応力状態にあるとき，その自由表面に一様な圧力を加えてる，その 鉛直一水平応力比は変化せず，一定に保たれる。

鉱石ペレットの弾性定数は著者らによって

$$
C_{1}=0.03, C_{2}=0.25, C_{3}=1.5\left(\mathrm{~mm}^{2} / \mathrm{kg}\right)
$$

と与えられているので,

(5) 式に代入して解くと

$$
K_{0}=0.34
$$

が得られる。

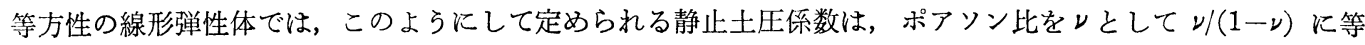
しいことは容易に導かれる。また，鉱石ペレットの内部摩擦角 $\phi=44^{\circ}$ を(2) 式に代入することにより得られる 瀞止土圧係数は 0.31 である。

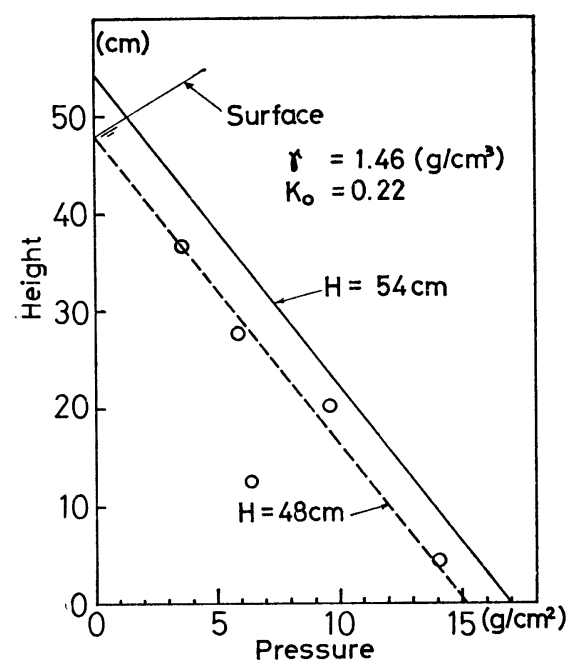

Fig. 2 珪砂が囲壁汇及ぽす圧力分布

\section{実験}

幅 $400 \mathrm{~mm}$ ，奥行 $100 \mathrm{~mm}$ ，前後面にアクリル板を張 り付けた容器に珪砂を最大深さ $600 \mathrm{~mm}$, 側壁での深さ $480 \mathrm{~mm}$ 入れ，側壁上の圧力分布を千々岩・畑村式圧力 計4)により測定した。その計測值をFig. 2 と示す。こ

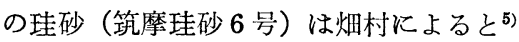

平均粒径 $0.2 \mathrm{~mm}$,

単位体積重量 $\gamma=1.46 \mathrm{~g} / \mathrm{cm}^{3}$

である。ここで著者により導かれた応力-歪関系の弾性 定数恃

$C_{1}=0.085, C_{2}=0.078, C_{3}=2.76\left(\mathrm{~mm}^{2} / \mathrm{kg}\right) \quad(8)$

となり,これより得られる静止土圧係数は（5）式より

$$
K_{0}=0.22
$$

と導かれる。静止土圧理論では, 水平圧力 $p$ は

$$
p=K_{0} r(H-y)
$$

であり (Fig. 2 参照), $H$ として側壁での深さ $(480 \mathrm{~mm})$ 


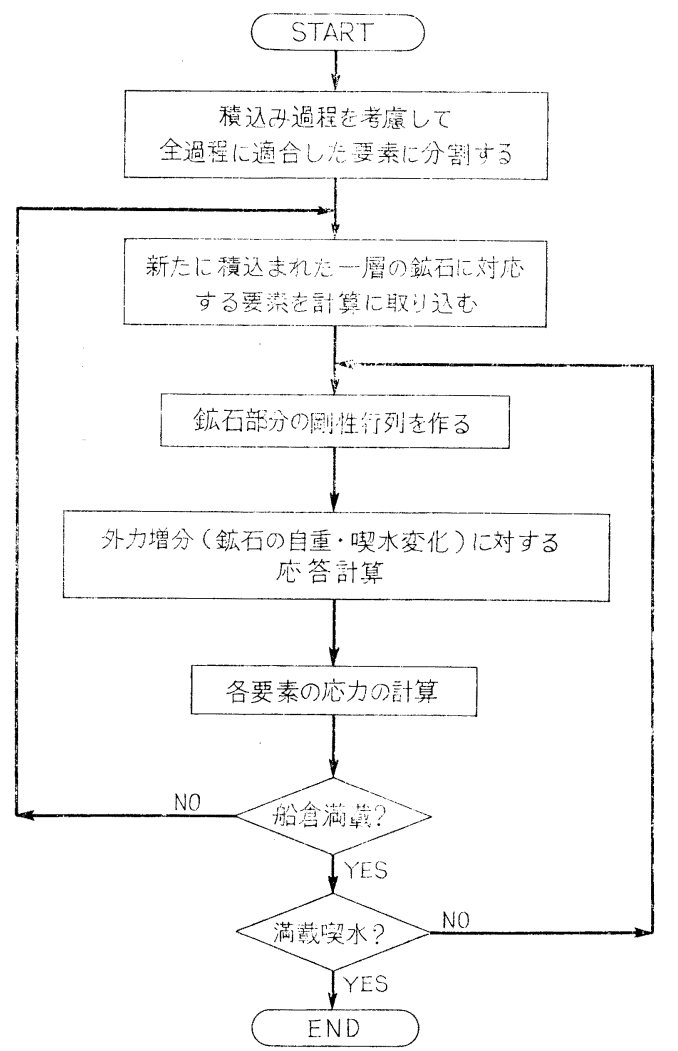

Fig. 3 積込及過程のシミュレーションの流れ困
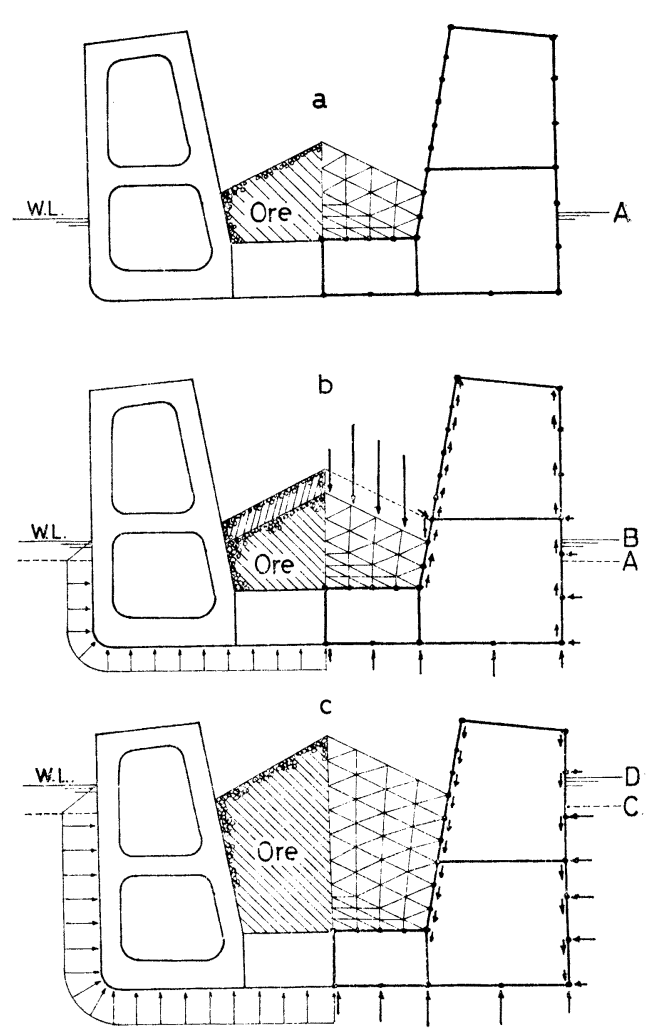

Fig. 4 積込み過程の再現

をとった理論値を鎖線で，また山積みの影響を考慮して，平均高さ $H=\{($ 側壁での高さ)+(最大高さ) $\} / 2$ を用 いた場合の理論值を実線で示す。実線に比べて鎖線の方が良い一致を示しているが，本論文では安全側の実線を 採用したい。なお，側壁の剛性は十分に剛である。

\section{3 皘込み過程のシミュレーション}

鉱石を船倉内に積み込むときに，実際には，鉱石は連続的に積み上がり，それにしたがって製水が連続的に変 化する。このような積込みのプロセスを数值的に再現するために, 積み込む過程を数段階に分け, 各段階での応 答を有限要素法により計算する (Fig. 3 参照)。

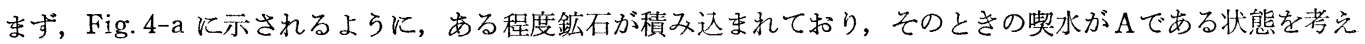
る。この状態の船にさらに一層の鉱石が積み込まれると契水は Fig. 4-b に示されるようにAから B に変化する。 したがって, Fig. 4-a の船体構造-鉱石の構造系を新たに加えた鉱石の自重による圧力と契水变化にともなら水 圧増加を外力として解析し，得られた応力増加を初期応力に加兄て，次の積込みプロセスの初期応力とする。

一般汇は，新たに積み込んだ鉱石の自重と契水変化による水圧とは平衡しない。これは，船首尾の予備浮力あ るいはバラスト水の出し入れによる䒜水調整などによるすのである。この三次元影響を考慮するために, 面内の 不平衡力は船側外板怙よび縦通隔壁の剪断力として受けるたれると考兄, これを外力として船体構造の二次元モ デルに加えて面内で外力を釣り合わせる。

この積込み過程を繰り返して, 考光ている横断面を満載にする（Fig. 4-c 参 照)。

次に，他の鉱石倉飞鉣石が積み込まれることにより，䒜水はこれまでのCより 満載契水に相当するD V変化するので，この契水变化に相当する水圧を外力とし て船体構造一鉱石の構造系に加光, 応力の増加量を初期応力に加光て最終的な応

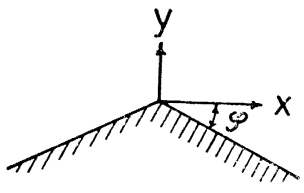

Fig. 5 
力分布とする。

この載荷の過程を第一層目の鉱石を積み込む段階より始めることにより満載時の鉱石圧分布が得られる。ここ で，新たに積み上げた層の応力は Nadai6)によって示された

$$
\begin{aligned}
\sigma_{x} & =-\sigma_{m}\left(1+\frac{y}{r} \sin \varphi\right) \\
\sigma_{y} & =-\sigma_{m}\left(1-\frac{y}{r} \sin \varphi\right), \sigma_{z}=K_{0} \sigma_{y} \\
\tau_{x y} & =\sigma_{m} \frac{x}{r} \sin \varphi
\end{aligned}
$$

ただし，

$$
\sigma_{m}=\gamma(-y+r \sin \varphi) / \cos ^{2} \varphi, r=\sqrt{x^{2}+y^{2}},
$$

であると仮定する (Fig. 5 参照)。この初期状態の設定は後の計算には汪とんど影響しない。また，鉱石が積み 込まれる以前の船体構造の変形は, 鉱石内の応力分布に何ら関係しないことをここに注意しておく。

計算にあたっては, 要素数を積込みの段階ごとに順次増加する必要がある。これは, 積み込む順序に要素番号 を付けることにより容易に解決される。また，全要素の応力テーブルを作成し，各積込みステップでの応力増加 を加觉ることにより，次のステップでの初期応力状態とすることは，他の非線形解析と同じ手法である。しか し, 各ステップでの要素数, 節点数が同じでないことは注意を要する。一般に, 各ステップで自由表面となる要素 境界の勾配は鉱石の安息角に等しい。このために，要素分割は安息角に平行な境界を持つようにする必要がある。

\section{4 解 析 例}

$1^{\circ}$. まず，萩原・谷7)によって実船実験が行なわれた富秀丸（56,100 DWT 日本郵船(株)所属）の積达み時 の鉱石圧分布を解析する。解析に用いた横断面の要素分割を Fig. 6 に示す。計算を簡単にするために，船体構 造は梁要素にモデル化し，その断面積怙よび断面二次モーメントは船の長手方向に一様であるとして平均化した 值を用いる。また，鉱石は三角形定需要素によりモデル化する。契水が，積み込むにしたがって $3 \mathrm{~m}$ から満載契 水の $12 \mathrm{~m}$ になる場合（このとき面内で鉱石の自重と水压が釣り合う）綎通隔壁に垂直な鉱石圧分布を Fig. 7 に示す。ここでは力学的特性として便宜上鉱石ペレットに対応するもの〔(6) 式参照]を用い，比重量 $\gamma$ 扣よび 壁面摩擦係数 $\mu$ は

$$
\gamma=2.2 \mathrm{~g} / \mathrm{cm}^{3}, \quad \mu=0.42
$$

とする。

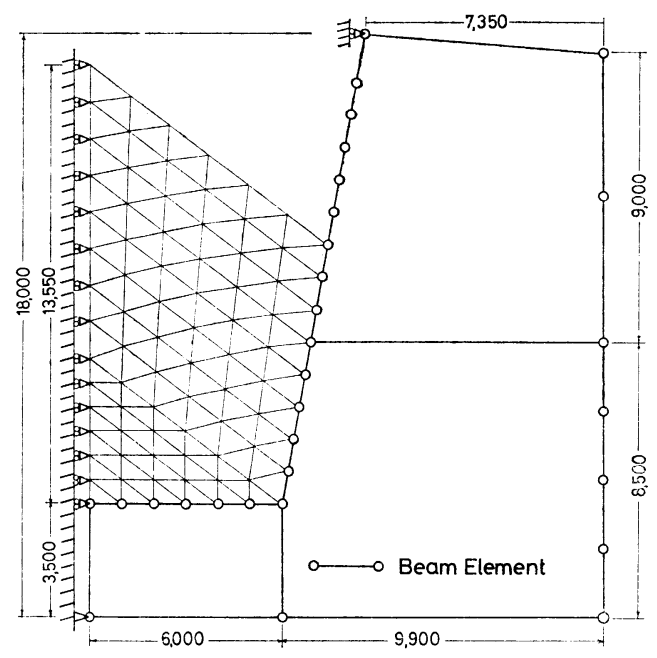

Fig. 6 有限要素法を用いて計算するための解析モデル
萩原・谷は本船に鉱石（粉鉱 $\gamma=2.66 \mathrm{~g} / \mathrm{cm}^{3}$ ) を 積み込んだときの鉱石圧分布を縦通隔壁背面に取り つけられた歪ゲージの出力より算定している。この

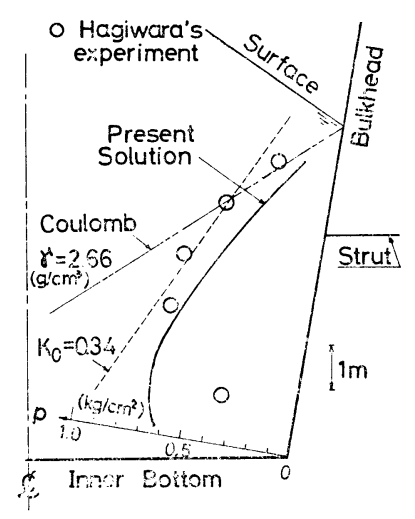

Fig. 7 萩原, 谷による実験（粉鉣）との比較 
值を同時に Fig. 7 そ○印で示す。また， $\gamma=2.66 \mathrm{~g} / \mathrm{cm}^{3}, \mu=0$ としたときの Coulomb 主働圧理論による分布 を二点鎖線で，静止土圧理論による分布を鎖線で示す。

シミュレーションの結果と実験值とは，隔壁下端をのぞいて，本計算が鉱石ペレットの諸係数を用いているこ とを考えれば，満足すべき一致を示している。また，自由表面の近傍では鉱石は塑性的であると考えられるの で, Coulomb 理論により漂ぼ近似できる。しかも，ある程度深い位置の鉱石圧は，鉱石の挙動が弾性的になり， 静止土压係数により尊かれる值により近似されることがわかる。山積の影響を考慮するために，ここでは一応等 価高さとして最大高さと壁面での高さの平均を提案する。

$2^{\circ}$. 前例と同じ解析モデルを用いて，積込みプロセスの違いによる鉱石圧分布の差をFig. 9 に示す。積込み プロセスとして次の四つの場合を考光る (Fig. 8 参照)。

（A）船倉全長にわたって同時に積込まれ，妿水は積込みとともに変化する（前例と同し）。

（B）軽荷状態にある船の極く短い一倉口だけに積み込む場合で，鉱石を積み込むことによる盁水変化はな く, その後, 他の倉口からも積み込をれることにより満載掣水となる。

（C）（B）之同様な短い倉口だけと積み込む場合だが,す でに他の倉口カらの積込みが終っておるために, 満載契 水に近い喫水状態で積み込みはじめる場合である。

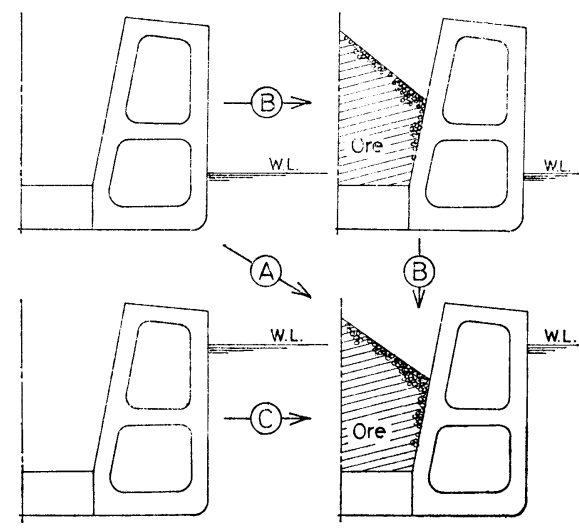

Fig. 8 各種の積込み過程

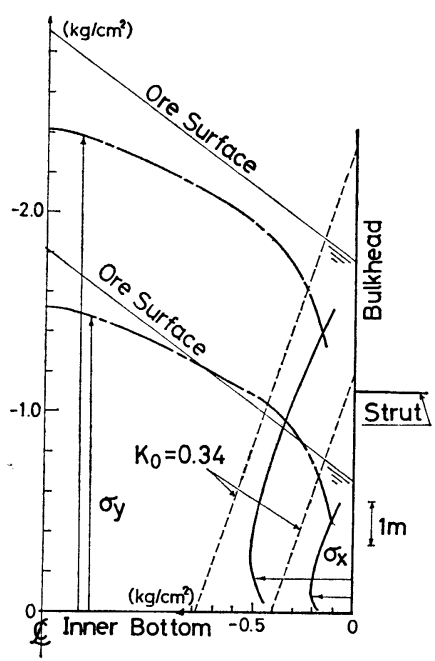

Fig. 10 垂直な縦通隔壁を持つ船倉の圧力分布

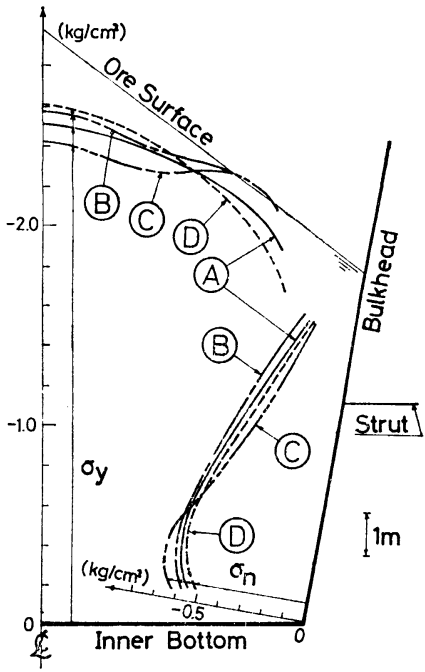

Fig. 9 積込み過程の違いによる氏力分布の差

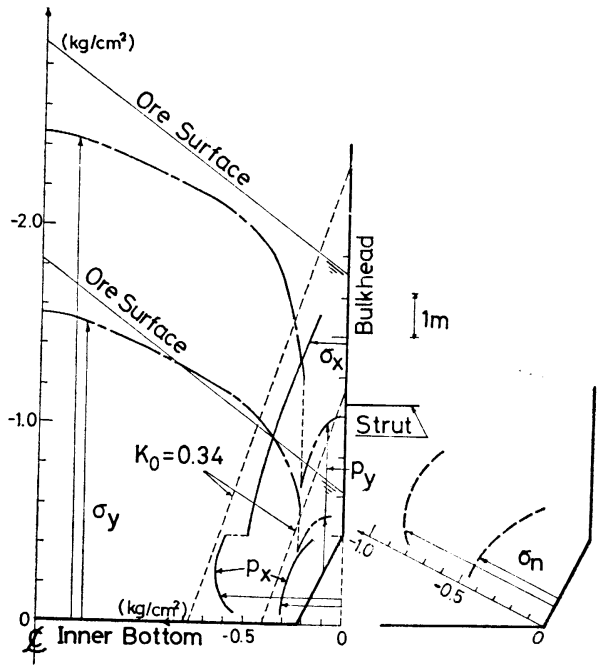

Fig. 11 斜板を持つ船倉の压力分布（その 1 ） 


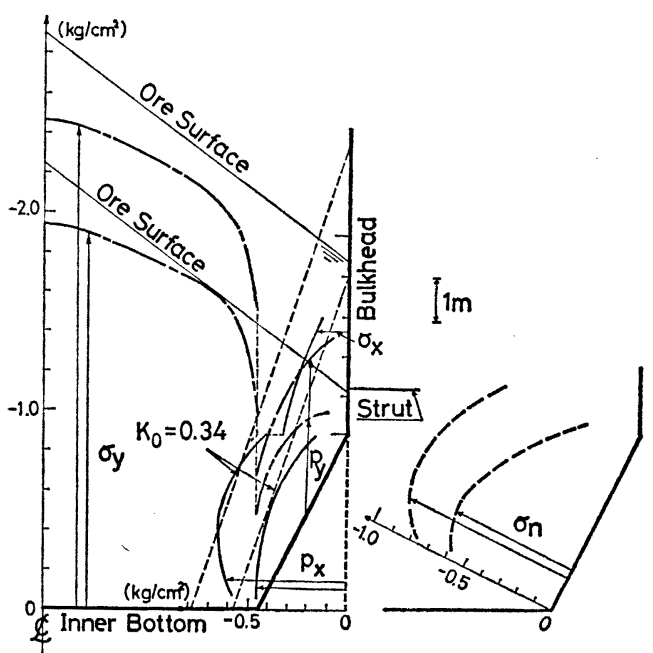

Fig. 12 斜板を持つ船倉の圧力分布（その 2)

（D）船倉壁が変形しない場合。すなわち剛な船体 に鉱石が積み込まれる場合。

$3^{\circ}$. 縦通隔壁が垂直の場合, および縱通隔壁下部に 斜板がある場合の倉内 の圧力分布を Fig. 10, 11, 12 に示す。ここでの桇水変化は前例の Aの場合とする。 積込み過程の中間段階での分布を同時に示すととる に, 静止土圧論による值を鎖線で示す。なお，Fig. 11， 12 に持いては, 斜板に加わる単位面積当りの鉱石力 $x, y$ 成分 $P_{x}, P_{y}$ を示す。

$4^{\circ}$. 以上の解析例で知られるように

1. 実船に掠ける鉱石の積み込みプロセスで，船体 の剛性および制水の変化は鉱石圧分布にあまり影響せ ずしたがって船体を剛としてこれを定めることがで きる。

2. 船倉側壁上の水平圧力の分布は, 斜板の有無に かかわらず，ほぼ直線的に分布する。その分布は静止 土圧係数を用いて近似することができ平均高さに対応する值を取れば安全側である。

3. 内底板拉よび斜板に加わる応力の鉛直成分は，考えている点から鉱石の自由表面までの距離に比例すると してよい。

\section{5 結言}

本論文に述べた積込み過程のシミューションの手法は，船体構造の剛性が鉱石の初期応力に及ぽす影響を明ら かにするばかりでなく，積込み過程の任意の䒜水変化をも考虑することができる。さらに，任意の船倉形状に対 しても容易に適用することができる。

終わりに，本論文を書くにあたり東京大学産業機械工学科助教授 長尾高明博士，同助教授 畑村洋太郎博士に 種々御教授を賜った。また東京大学船舶工学科 太田垣由夫氏，信原真人氏に実験に際し御協力を賜った。ここ そ深く感謝の意を表する。

\section{参 考 文 献}

1）山本善之, 浦 環, 松原典宏, 信太明人：粒状体の弾性挙動に関する基礎的研究，日本造船学会論文集第 132 号, (1972), pp. 249 256.

2) Y. Yamamoto and T. Ura : Elasto-Plastic Analysis of the Distribution of Ore Pressure on Longitudinal Bulkheads in an Ore Carrier, Selected Papers from J. S. N. A. of Japan, Vol. 12, (1974), pp. $149 \sim 155$.

3）山内豊聰, 安原一哉：粘性土の静止土圧係数に関する一考察, 土質工学会論文報告集, Vol. 14, No. 2, June (1974), pp. 113 117.

4）千ヶ岩健児, 畑村洋太郎：土括よび粉粒体用小形測定器の開 発, 日本機珹学会誌, 第 74 巻, 第 631 号, (1971), pp. 923〜933.

5）畑村洋太郎：土の切削機構の解明, 東京大学学位論文, (1972).

6) A. Nadai : Theory of Flow and Fracture of Solids, McGraw-Hill, Vol. 2, pp. 43う̄ 454.

7）萩原孝一，谷 昭夫：鉄鉱石によって船倉囲壁に加えられる荷重，三菱重工技報，Vol. 4, (1967)，pp. $631 \sim 635$. 